\title{
International Financial Governance, the EU, and Brexit: The 'Agencification' of EU Financial Governance and the Implications
}

\author{
Niamh Moloney ${ }^{1}$
}

Published online: 28 November 2016

(C) The Author(s) 2016. This article is published with open access at Springerlink.com

\begin{abstract}
This article argues that the forces which shape how the EU engages with international financial governance are changing and that the implications for the EU's ability to impose its preferences internationally are significant. It suggests that this change is being driven by two related factors. First, the European Supervisory Authorities (ESAs), with their distinct incentives, preferences and powers, have recently come to prominence in international financial governance. Second, as international financial governance pivots from being preoccupied with standard setting to becoming concerned with operational matters, there is greater potential for influence to be exerted by administrative actors such as the ESAs. This article uses the European Securities and Markets Authority-which is the most active ESA internationally — as a case study for examining the implications of the availability of a technocratic administrative channel through which the EU can engage with international financial governance. It also offers some predictions as to the implications of the Brexit decision for the ESAs as international actors and for the UK's interaction with international financial governance.
\end{abstract}

Keywords Brexit · European Supervisory Authorities · European Securities and Markets Authority · International financial governance · IOSCO · IFRS Foundation

I am grateful to Professor Eilís Ferran and to the EBOR referee for their comments and to Professor Pierre-Henri Conac for discussions on this topic.

Niamh Moloney: Professor of Financial Markets Law.

Niamh Moloney

N.Moloney@1se.ac.uk

1 Law Department, London School of Economics and Political Science, London, UK 


\section{Brexit, the EU, and International Financial Governance}

The 'Brexit' decision of 23 June 2016 has generated intense discussion and speculation on the nature of the UK's future relationship with the EU. ${ }^{1}$ At the time of writing there are few indications as to the likely shape of the arrangements which will govern the relationship between the UK and the EU-27-whether customs union, free trade area, European Economic Area (EEA), or other variant. It can be predicted with a reasonable degree of certainty that the process of extracting the UK from EU financial governance-within which the UK financial system is deeply embedded-will be complex and lengthy. It can also be predicted reasonably safely that the nature of the UK's influence on international financial governance will change on exit from the EU. This will be in no small part because the UK will no longer be represented on the EU's European Supervisory Authorities (ESAs), which are becoming increasingly influential on international financial governance. The primary purpose of this article is to consider why and how the means through which the EU engages with international financial governance are changing, and the implications of this. Given that, almost contemporaneously with the ESAs becoming more active in international financial governance, the UK will be withdrawing from the ESAs, the article also offers some predictions as to how Brexit is likely to shape UK and EU interaction with international financial governance.

International financial governance is usually characterised as the system which imposes standards on the global financial market, supports market access, and facilitates supervisory and regulatory coordination, primarily by means of the different measures adopted by the international standard-setting bodies (ISSBs); the ISSBs are typically composed of national regulatory authorities and/or central banks and ministries of finance, depending on the ISSB's particular mandate. ${ }^{2}$ The main ISSBs are the Financial Stability Board (FSB), the Basel Committee on Banking Supervision (Basel Committee), the International Organization of Securities Commissions (IOSCO), the International Financial Reporting Standards (IFRS) Foundation, and the International Association of Insurance Supervisors (IAIS). These ISSBs have, by implementing high-level political directions from the G20, come to play a determinative role in re-shaping domestic, regional, and international financial governance in the wake of the 2008 financial crisis. ${ }^{3}$ In the EU, the G20 reform agenda provided the template which the EU used to re-cast regulatory governance. ${ }^{4}$ The Basel III Accord reforms to the regulation of bank capital, liquidity, and leverage, and the IFRS 9 reforms to how banks report on impaired assets, to take only two from a multitude of examples of ISSB standards, are bringing fundamental change to how banks in the EU lend, manage risks to their balance sheets, and report to the financial markets. To take a current example, the

\footnotetext{
1 See, e.g., the collection of essays in the July 2016 special edition of the German Law Journal (17 Germany Law Journal 2016), available at http://www.germanlawjournal.com/brexit-supplement.

2 See Avgouleas (2012) and Davies and Green (2008).

3 For a recent review, see Quaglia (2014a).

4 Ferran (2012a) and Moloney (2010).
} 
EU is currently assessing how to address the important new 'TLAC' (total loss absorbing capacity) standards for global systemically important banks (G-SIBs), which are a key element of the post-crisis global framework for addressing orderly bank resolution and which were adopted by the FSB in November $2015,{ }^{5}$ and how the TLAC standards will relate to the similar 'MREL' (minimum own funds and eligible liabilities) requirements which apply to banks and investment firms in the EU.

Given that international financial governance shapes EU financial governance, the extent to which the EU can impose its preferences matters. So does the relative effectiveness of the channels through which the EU engages with international financial governance. This article suggests that the nature of the EU's engagement with international financial governance is changing and that these changes are likely to strengthen the EU's ability to impose its preferences. It identifies two factors which are re-shaping how the EU engages with international financial governance. First, the ESAs have opened up a new administrative channel for EU engagement: the European Securities and Markets Authority (ESMA) is the most active internationally, followed by the European Banking Authority (EBA) and the European Insurance and Occupational Pensions Authority (EIOPA). Second, international financial governance is more readily accommodating the preferences of administrative actors such as the ESAs as it pivots from being mainly preoccupied with standard setting (in relation to which national political interests have traditionally been paramount) to adopting a more operational posture (in relation to which the interests of administrative financial regulators are becoming increasingly paramount). The article takes ESMA as a case study-as the most active ESA internationally - and considers whether, as an administrative actor, it is strengthening the EU's ability to impose its preferences as international financial governance becomes more operational in nature. It suggests that ESMA and the other ESAs have the potential to become significant actors in international financial governance and to strengthen, as a result, the EU's ability to impose its preferences. Additionally, it suggests that the ESAs may enhance the effectiveness of international financial governance by strengthening its ability, as a system, to ensure that standards are treated as obligations and that related monitoring and enforcement systems are in place. ${ }^{6}$ The article also speculates that the UK's influence on international financial governance is likely to diminish, given that it will no longer be represented on the ESAs.

Section 2 situates the analysis within the literature and contextualises the current dynamics of international financial governance. Section 3 considers the incentives and powers of the ESAs with respect to international financial governance, and Sect. 4 examines ESMA as a case study. Section 5 considers the implications of the Brexit decision. Section 6 concludes. ${ }^{7}$

\footnotetext{
5 FSB (2015a).

6 This conceptualisation of effectiveness draws on Barr (2014).

7 Some elements of the analysis in Sects. 2 and 3 draw on arguments outlined in Moloney (2017).
} 


\section{EU 'Agencification' and International Financial Governance: Literature and Context}

\subsection{Situating the Analysis}

Scholarly inquiry into international financial governance falls primarily within the fields of international financial law and of international and comparative political economy, ${ }^{8}$ although discussions typically identify a scarcity of scholarship. ${ }^{9}$

Legal scholarship typically adopts an effectiveness-oriented perspective and considers how international financial governance achieves outcomes, including through its governing institutions. Its main concern is with explaining how and why international financial governance, although primarily based on soft standards and on informal networks of domestic regulators operating through the ISSBs, can exert coercive force ${ }^{10}$ and overcome the risks to its durability posed by major global crises. ${ }^{11}$ A related body of legal scholarship probes the accountability and legitimacy risks which derive from the network- and soft-law-based nature of international financial governance and the mitigating procedural devices which are evolving. ${ }^{12}$ The increasingly rich legal literature on the ESAs, however, has yet to focus closely on their role as administrative actors in international financial governance. ${ }^{13}$ But while somewhat sparse, this composite legal literature supports discussion of the challenges which the ESAs face in engaging with international financial governance as administrative actors and of how their capacities and powers can shape EU engagement.

The international political economy and comparative political economy literature provides tools of analysis for examining the power dynamics of international financial governance and how different preferences are imposed. ${ }^{14}$ It therefore sheds light on the context in which the ESAs operate. This literature has classically characterised international financial governance as being a function of the preferences of the 'great

\footnotetext{
8 The experimentalist governance strand of regulatory theory, which examines the flexible and responsive governance tools beyond traditional 'command and control' legislation that can be used to achieve outcomes, also considers international financial governance, particularly with respect to the different tools which the ISSBs deploy. See Campbell-Verduyn and Porter (2014).

9 From a legal perspective, see, e.g., Brummer (2011), and from a political economy perspective, see Mügge (2014a) and Quaglia (2014b).

10 See, e.g., Brummer (2014), Brummer (2012), Kelly and Cho (2011), and Yadav (2010). Much of this analysis builds on the network theory of international law: Slaughter (2004).

11 See, e.g., Verdier (2013), Pan (2010), and Zaring (2009).

12 See, e.g., Barr (2014) and Barr and Miller (2006).

13 Relevant scholarship has focused primarily on the EU's role and approach generally and probes the lessons which international financial governance might draw from the EU experience. Key contributions include Ferran (2014) and Amtenbrick (2013).

14 For a review of the literature, see Helleiner and Pagliari (2011). On the political economy of, e.g., EU/ US relations generally with respect to financial services, see Dür (2011) and Posner and Véron (2010).
} 
powers' in finance- - the US ${ }^{15}$ and also, increasingly, the EU. ${ }^{16}$ But the EU's ability to act as a 'great power' is constrained. The deep-seated institutional structures which shape different national economies and financial systems in the EU (and which have been charted by the Varieties of Capitalism literature ${ }^{17}$ and recent discussions on the blurring of the classic market- and bank-based economy structures ${ }^{18}$ ) also shape national regulatory preferences and drive divergence. Distinct Member State regulatory preferences, the extent to which such preferences cohere to an EU approach, and the related and varying ability of the EU to 'up-load' its preferences internationally, to 'down-load' international standards, and to 'cross-load' its preferences to third countries, have been identified as leading to differing degrees of EU influence on international finance governance over time. ${ }^{19}$ The Basel III Accord negotiations, for example, saw differences between the negotiating positions of the EU and of its Member States, reflecting structural differences in banking markets across the EU and related divergences in national preferences. ${ }^{20}$ The EU presence as a 'great power' in international financial governance is likely to be strong where either the Member States can coordinate their distinct national preferences or-typically where the distributional effects are weaker and structural differences across national economies and financial systems less relevant-there is extensive delegation to representative EU agents. ${ }^{21}$ And here the international political economy literature provides an important insight. It posits that administrative agencies can shape and diffuse preferences by supporting the 'regulatory capacity' of the state—or the state's ability to achieve desired outcomes through the adoption, monitoring, and enforcing of rules. ${ }^{22}$ With the requisite regulatory capacity, state preferences can be imposed through, for example, third-country market access/equivalence mechanisms which require third countries to follow the state's regulatory approach. The extent of a state's regulatory capacity also shapes its ability to transmit, through its domestic regulators, national regulatory preferences to the international level. ${ }^{23}$ The EU's regulatory capacity generally (legislative and administrative) has accordingly been identified as of central importance to its degree of influence on international financial governance, whether exerted through its use of equivalence/access mechanisms, its direct influence on the negotiation of international standards, or its ability to 'harden' soft standards globally by adopting them for the EU. ${ }^{24}$ But the political

\footnotetext{
15 See, e.g., Drezner (2007).

16 Mügge (2014b). The EU financial market is second only to the US market in size. Recent analysis by the Commission undertaken in the context of the Capital Markets Union agenda notes that, as at end 2013, EU stock market capitalisation stood at $€ 8.4$ trillion ( $64.5 \%$ of GDP), while the value of outstanding debt securities was $€ 22.3$ trillion (171.3\% of GDP): European Commission (2015), at pp. 10-11.

17 The foundational work is Hall and Soskice (2001), which, very broadly, distinguishes between bankand market-based economies.

18 See, e.g., Hardie and Howarth (2013).

19 On 'up-loading', 'cross-loading', and 'down-loading', see Quaglia (2014a).

20 See Howarth and Quaglia (2015).

21 Mügge (2011).

22 In the political economy literature regulatory capacity is associated with the ability of a state to formulate, monitor, and enforce rules: Bach and Newman (2007). For a recent examination in the context of the EU's global relations generally, see Newman and Posner (2015).

23 See, e.g., Quaglia (2014a) and Büthe and Mattli (2011).

24 See, e.g., Bach and Newman (2014), Posner (2009), and Posner (2010).
} 
economy literature has yet to closely examine the ESAs and how they, by strengthening the EU's regulatory capacity by providing a new administrative channel for the formation and diffusion of EU preferences, may reshape EU engagement. ${ }^{25}$

This article is primarily situated within a legal analytical framework. It probes how particular powers, legal tools, and institutional/constitutional constraints and incentives at the administrative ESA level, and particular at the ESMA level, are reshaping how the EU engages with international financial governance. But it draws on a composite literature to support its examination of how the ESAs' powers, preferences, and incentives may lead to change and of how the effectiveness of international financial governance more generally may be affected.

\subsection{The Context: The Changing Nature of International Financial Governance}

Prior to the financial and subsequent euro area crises which beset the EU over 2008-2012, the EU was becoming an influential actor in international financial governance. $^{26}$ Over the crisis-era reform period (2008-2014) this influence increased as the EU became a force in the major ISSBs and sought to export its approach to financial governance globally as the G20 reform agenda was implemented. $^{27}$ The major elements of the massive G20 reform agenda are now in place. ${ }^{28}$ The extent to which the EU's preferences have shaped the related international standards and/or have led to the filtering and calibration of international standards during the EU implementation process to reflect EU interests can now be seen. ${ }^{29}$ So too can the success or otherwise of the EU in "crossloading' its crisis-era rules to third countries through its market access and equivalence mechanisms. ${ }^{30}$ However, changes to the nature of international financial governance are underway and these are likely to strengthen the EU's ability to impose its preferences.

International financial governance is currently pivoting from being primarily preoccupied with the agreement of standards to becoming mainly concerned with the achievement of outcomes. This pivot has brought with it a focus on the finessing

\footnotetext{
25 Brief reference to the ESAs' potential role in international financial governance has been made by leading international political economists, such as Mügge and Quaglia, but their focus has primarily been on Member State power relations. See, e.g., Mügge (2014b) and Quaglia (2014a), at pp. 180-181.

26 Examples include the resolution of the 'Hotel California' problem which prevented EU (or any) firms from delisting (exiting) from US exchanges (demand for delisting increased following the adoption of the 2002 Sarbanes-Oxley Act and its related imposition of disclosure and corporate governance requirements) where they had 300 shareholders in the US. Following EU/US negotiations, a delisting mechanism based on global trading volumes was adopted in 2007.

27 For a consideration of the major developments, see Moloney (2017).

28 As is clear from the regular progress reports from the FSB to the G20: recently, FSB, Chair's Letter to G20 Finance Ministers and Central Bank Governors, 19 July 2016.

29 See, e.g., Quaglia (2015) and Blom (2014). The divergences between the EU's banking regime (Directive 2013/36/EU, OJ 2013 L176/338, and Regulation EU No 575/2013, OJ 2013 L176/1) and the Basel III Accord have been charted with some concern by the Basel Committee (2014a).

30 The EU has been particularly successful in 'cross-loading' its credit rating agency regulation through third-country access/equivalence rules. Moloney (2014a), at pp. 677-682.
} 
of standards, the monitoring of standard implementation and the management of related divergences, the coordination of supervision and enforcement, and data collection and assessment. Related operational coordination, and the management of divergent approaches to and styles of financial governance, have come to define much of international financial governance engagement, reflecting the characterisation of post-crisis international financial governance as a form of 'mutual adaptation' and of 'co-operative de-centralization'. ${ }^{31}$ The FSB, for example, is engaging in regular and intensive peer reviews of how crisis-era standards are being implemented, ${ }^{32}$ while the Basel Committee is carrying out intensive Regulatory Consistency Assessment Programmes (RCAPs) of Basel III Accord implementation by its members internationally and reviewing implementation more generally. ${ }^{33}$ Similarly, the IAIS has adopted a Coordinated Implementation Framework to support the implementation of insurance standards. Standards are also being finessed by the ISSBs as empirical data on their impact emerges. ${ }^{34}$ Supervisory coordination arrangements are being hammered out, with the effectiveness of colleges of supervisors increasingly the concern of the ISSBs. ${ }^{35}$ The quality of supervision is receiving close attention under the Financial Sector Assessment Program (FSAP) assessments now required of all FSB members, which review, inter alia, the IOSCO Objectives and Principles of Securities Regulation (2010) (which cover supervision) and the Basel Core Principles for Banking Supervision (2012). ${ }^{36}$ Enforcement-hitherto not a major concern of international financial governance-is becoming a priority. ${ }^{37}$ Similarly, IOSCO and the FSB are focusing closely on the management of conduct risk and on related enforcement-a classic operational concern of domestic regulators but a new area of interest for the ISSBs. ${ }^{38}$ The operational details of market access arrangements are also receiving close attention, particularly from IOSCO. ${ }^{39}$ Coordinated efforts are being made through the ISSBs to understand, manage, and interrogate the vast data set now emerging from the new crisis-era reporting requirements ${ }^{40}$ and to monitor global

\footnotetext{
31 Helleiner and Pagliari (2011).

32 Based on Financial Stability Board (2015b). See Gadinis (2013a).

33 See recently Basel Committee (2016).

34 Such as the July 2015 review by the Basel Committee of the Basel III Credit Valuation Adjustment (CVA) capital charge. The review reflects experience with the hedging techniques banks have adopted in response to the CVA charge: Basel Committee (2015).
}

35 IOSCO, e.g., has adopted principles for rating agency supervisory colleges (IOSCO 2013), and the Basel Committee, which has a Task Force on Supervisory Colleges, has adopted principles for bank colleges (Basel Committee 2014b). The FSB recently carried out a thematic review of the operation of bank colleges (FSB 2015c).

36 Recent examples include the April 2015 FSAP report on the US system (IMF 2015).

$37 \operatorname{IOSCO}(2015 \mathrm{a})$.

38 IOSCO (2016) and FSB (2015d).

$39 \operatorname{IOSCO}(2015 b)$.

40 Coordination measures are underway with respect to the management and use of the massive data set now emerging from the OTC derivatives markets [e.g., FSB (2015e), noting challenges in relation to regulatory access to and the usability of the data now held by trade repositories (at pp. 21-22)]. Similar concerns, as well as progress on remediation, was reported in FSB (2015f). 
risks. ${ }^{41}$ Bilaterally, agency contacts and skirmishes are intensifying as the technical requirements for market access are coordinated. ${ }^{42}$ This change in posture is likely to herald a more prominent role for regulators in international financial governance. The distributional effects of international financial governance imply that national political interests will continue to exert a strong influence, particularly on the ISSBs. ${ }^{43}$ But these effects are likely to weaken as international financial governance becomes more operational. Regulatory agencies and their powers, interests, and preferences can be expected to become increasingly influential. The current international environment is therefore likely to be accommodating for the recent 'agencification' of the mechanisms through which the EU engages with international financial governance, namely the ESAs.

\section{The ESAs and the 'Agencification' of International Engagement: Powers and Incentives}

\subsection{The ESAs and International Financial Governance}

The 2011 reorganisation of the institutional structure supporting EU financial governance by means of the establishment of the European System of Financial Supervision, which includes the ESAs as well as national financial regulators, was internally focused. It was designed to address EU-specific challenges relating to the management of pan-EU risk transmission. But with it has come a spill-over change to the regulatory capacity of the EU with respect to international financial governance.

The management of the EU's international financial relations with the ISSBs is, for the most part, split between the supranational and national elements of EU governance: the Commission (as the EU's supranational, executive body) and the ECB (depending on the issue at hand), on the one hand; and the Member States, which are usually dominant and typically seek to impose their distinct national preferences, on the other. The European Parliament is not a representative actor in international financial governance. It is, however, increasingly seeking to exert oversight over the EU's international engagement. It has recently expressed concern as to the potential for a lack of accountability and transparency in the actors of international financial governance to subvert the democratic process in the EU. ${ }^{44}$ The Commission usually represents the collective EU interest (where one can be

\footnotetext{
41 In relation to which the FSB is playing a prominent role: e.g., FSB (2015g).

42 Particular difficulties persist with conflicts, inconsistencies, and duplication with respect to OTC derivatives market regulation, despite the November 2014 Brisbane G20 Summit's call for jurisdictions to show 'deference' to other systems where possible. US and EU discussions have progressed, however, with the Commission ruling in March 2016 that US regulation of central clearing counterparties (CCPs) is equivalent for the purpose of EU market access, following agreement in February 2016 between the Commission and the US Commodities Futures Trading Commission on a 'common approach'.

43 These interests may be all the stronger given the intensification of political oversight over regulators over the crisis era: Gadinis (2013b).

44 European Parliament (2016).
} 
established) internationally, although the ECB also participates where monetary and, since the establishment of Banking Union's Single Supervisory Mechanism (SSM), bank supervisory matters arise. ${ }^{45}$ In the FSB, the Commission and the ECB are currently members of the 54-member decision-making plenary session, along with the UK, France, Germany, Italy, the Netherlands and Spain (represented by their finance ministries, central banks, and/or other regulators). In the Basel Committee, the ECB — which has two 'seats' (one as monetary authority and one as bank supervisor within the SSM) - sits alongside the national bank regulators and central banks of Belgium, France, Germany, Italy, Luxembourg, the Netherlands, Spain, Sweden, and the UK as a full voting member-although in practice the Basel Committee operates by consensus. The Commission has non-voting observer status. $^{46}$ On IOSCO, the Commission has associate member (non-voting) status, while the EU's national securities markets regulators are ordinary voting members and six national regulators are permanent members of the 33-member decisionmaking (standard-setting) IOSCO Board (France, Germany, Italy, the Netherlands, the UK, and Spain). ${ }^{47}$ The Commission sits (with voting rights) on the oversight body of the IFRS Foundation-the IFRS Foundation Monitoring Board-together with a number of major (non-EU) regulators and IOSCO. On the IAIS, the Commission is a member of the general meeting, along with the EU's national insurance regulators, but it does not exercise voting rights. The 24-member IAIS executive committee, which has five national regulator members, does not include the Commission. ${ }^{48}$

The incentives and preferences which shape the EU's engagement with international financial governance through the ISSBs are therefore complex and inter-related, and EU and national interests co-exist and are represented through multiple channels. But since the 2011 establishment of the ESAs the nature of the EU's engagement with international financial governance, and of the related incentives and preferences, has begun to change. Under their founding regulations, ${ }^{49}$ the ESAs have a series of quasi-regulatory and supervisory powers. ${ }^{50}$ They can propose certain forms of administrative rule ('Binding Technical Standards') for adoption by the Commission, provide the Commission with 'Technical Advice' on administrative rule-making generally, and adopt different forms of soft law. They have also been conferred with a range of supervisory coordination and convergence powers, including data collection and peer review powers, the power to review certain national supervisory decisions, and powers in relation to ESA participation

\footnotetext{
45 For an account of the ECB's representative functions internationally, see Letter from ECB President Draghi to MEP Sven Gielgold, 17 December 2015 (L.MD/15/683).

46 Quaglia (2015).

47 In addition, three EU regulators are currently elected to the Board (Belgium, Greece, and Sweden): Conac (2015).

48 Lowet (2015).

49 European Banking Authority (EBA) Regulation (EU) No 1093/2020, OJ 2010 L331/12; European Insurance and Occupational Pensions Authority (EIOPA) Regulation (EU) No 1094/2010, OJ 2010 L331/ 48; and European Securities and Markets Authority (ESMA) Regulation (EU) No 1095/2010, OJ 2010 L331/84.

50 See, e.g., Moloney (2014a), at pp. 854-1009, Busuioc (2013), and Schammo (2011).
} 
in colleges of supervisors; a limited range of powers to direct national regulators in specified circumstances; and, in the case of ESMA, specified direct supervisory and enforcement powers over a limited group of market participants and activities (credit rating agencies, OTC derivatives market trade repositories, position management, short selling, and the marketing of certain investment products ${ }^{51}$ ).

The ESAs have also been given a series of powers with respect to international financial governance. These administrative powers address supervisory cooperation and coordination, including the facilitation of information exchange and of cooperation agreements between Member State regulators and third countries, and participation in international organisations. ${ }^{52}$ They also relate to the EU's multiplicity of equivalence-based market-access mechanisms, in relation to which the ESAs are typically empowered to advise the Commission as to whether a particular third country's financial governance arrangements are equivalent to those of the EU. ${ }^{53}$ The ESAs' relatively limited formal powers do not, however, fully reflect the extent to which the ESAs have de facto constructed a new administrative channel for EU engagement with international financial governance, as is discussed with respect to ESMA in Sect. 4.

\subsection{Aligned Incentives and Powers?}

While all three ESAs have a similar set of formal powers with respect to international financial governance, they also share related incentives and preferences. The ESAs, established in 2011, are still youthful administrative actors, but they are maturing and testing their powers - and they are doing so under the 'shadow of hierarchy', 54 notably the Commission's 'shadow', which has the potential to significantly shape their incentives and preferences. This shadow relates to the nature of administrative governance in the EU. The regulatory demands of the single market have led to a massive expansion in the EU administrative state and to a related material 'agencification' of EU governance generally. ${ }^{55}$ But the operating environment for EU agencies is highly restrictive. With respect to rule-making - the typical province of domestic agencies-under the EU Treaties the Commission is the constitutional location for administrative rule-making. However functionally desirable it may be, technocratically expert EU agencies may not adopt administrative rules. With respect to supervision-similarly the usual province of domestic agencies-EU constitutional arrangements prevent agencies from being empowered to take discretionary decisions unless appropriate conditions apply, in order to

\footnotetext{
51 EBA is also empowered to prohibit certain deposit-related investment products.

522010 EBA, EIOPA and ESMA Regulations, Art. 33 empower the ESAs to develop contacts and enter into administrative arrangements with supervisory authorities, international organisations, and the administrations of third countries. More specific ESA powers relating to international coordination and information exchange are contained in the sectoral directives and regulations of EU financial regulation.

53 Art. 33 requires the ESAs to assist in preparing equivalence decisions. More specific requirements relating to assisting the Commission on equivalence decisions, and directions as to the issues the ESAs must consider, are set out in the sectoral directives and regulations of EU financial regulation.

54 See Héritier and Lehmkuhl (2008).

55 For discussion, see Craig (2015).
} 
protect the institutional balance set up under the Treaties (the famous Meroni doctrine $^{56}$ ). Accordingly, the Commission is the administrative rule-maker for the EU financial system, and the ESAs' ability to take supervisory decisions is constrained. ${ }^{57}$ The ESAs have therefore strong incentives to assert their institutional position and to strengthen their credibility as regulatory agencies through means which do not threaten the constitutional and political limits within which they operate. ${ }^{58}$ The operational/coordination activities which currently define international financial governance make available to the ESAs a sphere of operation which is relatively uncontroversial. They also provide potentially fruitful opportunities for expert specialisation and for the strengthening of the ESAs' institutional position which are relatively free from political and constitutional constraints and risks. This is all the more the case as the ESAs are currently being relieved of the intense resource burdens associated with the delivery of the administrative standards required under the crisis-era regulatory reform programme. All three ESAs have until recently been primarily preoccupied with quasi-regulatory matters. EIOPA's activities have been dominated by the vast administrative rule-book required for the Solvency II regime. ${ }^{59}$ EBA has been focused on the delivery of the rules which support the behemoth 2013 Capital Requirements Directive IV/Capital Requirements Regulation regime and the 2014 Bank Recovery and Resolution Directive. ${ }^{60}$ ESMA has had the heaviest load to carry in terms of rule development-its mandate included the dense administrative rule-book required for the 2014 Markets in Financial Instruments Directive II/Regulation, ${ }^{61}$ the leviathan of EU financial market regulation. That regulatory pressure is now lifting and the extent to which the ESAs are now turning to the more operational supervisory convergence and coordination activities which are beginning to shape international financial governance is striking, as is clear from-to take only a representative sampleESMA's new supervisory convergence agenda; ${ }^{62}$ EBA's multi-faceted activities related to the 'SREP' (the operational Supervisory Review and Evaluation Process required to be undertaken by the supervisors of EU banks); ${ }^{63}$ and EIOPA's 2015-2017 work programme on supervision. ${ }^{64}$

The persistence of structural differences across national economies and financial systems in the EU and of related divergences in national regulatory preferences, as well as the intergovernmental quality of ESA Board of Supervisors decision-making (decision-making is the prerogative of the national regulators who sit on the Boards and operate under a qualified majority vote), limit the extent to which the ESAs can

\footnotetext{
56 Case 9/56 Meroni v High Authority [1957-1958] ECR 133.

57 See further Moloney (2014a), at chapters X and XI.

58 Ibid, at pp. 976-1007.

59 Directive 2009/138/EU, OJ 2009 L335/1.

60 Directive 2013/36/EU, OJ 2013 L176/338, and Regulation EU No 575/2013, OJ L 2013 176/1; and Directive 2014/59/EU, OJ 2014 L173/90.

61 Directive 2014/65/EU, OJ 2014 L173/349, and Regulation (EU) No 600/2014, OJ 2014 L173/84.

62 ESMA (2016a).

63 See, e.g., EBA (2014) and EBA (2016a).

64 EIOPA (2015a), at pp. 7-9.
} 
operate as representatives of collective EU preferences. So also do the competences of the Commission and the ECB with respect to the ISSBs. But it is nonetheless becoming clear that the ESAs are creating a new mAgreement which governs cooperation andeans for the EU to engage with international financial governance and the ISSBs. All the ESAs are represented on their major sectoral ISSBs. Unlike the Commission, EIOPA is a voting member of the general meeting of the IAIS and of the IAIS executive committee. ${ }^{65}$ The EBA position is different. By contrast with the Commission and ECB, EBA does not have a formal, voting presence on the Basel Committee. It has, nonetheless, considerable opportunities to exert influence, being represented by its Chairperson on the Basel Committee's influential Group of Governors and Heads of Supervisors and by its Executive Director in the plenary session of the Basel Committee; it is also represented in a number of working groups. ${ }^{66}$ While EBA cannot vote, in practice Basel Committee discussions are consensus based and EBA is technically well equipped to represent the collective interests of EU banking regulators, where any can be established. ${ }^{67}$ As discussed in Sect. 4, ESMA is represented on IOSCO and is actively engaged with the IFRS Foundation. Across the IAIS, Basel Committee, IOSCO, and the IFRS Foundation, the three ESAs are all, albeit to different degrees, active and, again to different degrees, are displaying a strengthening regulatory capacity to exert influence and impose EU preferences.

While the ESAs have much in common with respect to international financial governance, this discussion focuses on ESMA as the operating environments of the ESAs internationally are in some respects distinct. In the case of EIOPA, although it has asserted its commitment to engagement with the IAIS $^{68}$ and is a permanent member of the IAIS executive committee, international financial governance in the area of insurance is less well developed as compared to in the banking and securities markets. The IAIS was established in 1994 (the Basel Committee and IOSCO were established in 1974 and 1983 respectively) and has only recently come to prominence in international financial governance. Its activities intensified as the global reform agenda turned to financial stability over the financial crisis, in particular following the establishment of the FSB in 2009 and the related priority given to the identification and management of the risks of global systemically important insurers and to the adoption of international capital standards for globally active insurance groups. The IAIS is also increasingly active with respect to information exchange, supervisory coordination, and peer review. ${ }^{69}$ There is, nonetheless, only a relatively limited empirical basis for examination of EIOPA, although initial indications suggest an influential EIOPA voice on the IAIS and an EIOPA commitment to international engagement. ${ }^{70}$

\footnotetext{
65 Lowet (2015), at pp. 15-16.

66 Quaglia (2015), at p. 12.

67 For discussion of EBA's role in the Basel Committee, see Moloney (2017) and Quaglia (2015).

68 See, e.g., EIOPA (2015a), at p. 12.

69 See recently IAIS (2014).

70 Lowet (2015). In July 2016, e.g., EIOPA joined the IAIS International Information Exchange Agreement which governs cooperation and information exchange between insurance supervisors internationally.
} 
By contrast with EIOPA, EBA operates in a sophisticated and mature segment of international financial governance, the main architecture for which is provided by extensive Basel Committee and FSB standards. EBA has, however, distinct incentives to the other two ESAs with respect to international engagement which derive from the increasingly brittle institutional architecture that supports EU banking governance. This brittle quality is a function of the disjunction between the institutional governance of the single banking market (covering the EU's current 28 Member States and EBA's remit) and that of Banking Union/the SSM (currently covering the euro area's 19 Member States and primarily the remit of the ECB within the SSM). EBA is charged with supporting the amplification and application of the EU's single banking rule-book through its quasi-rule-making powers. It is also charged with driving pan-EU supervisory convergence in how this rule-book is applied. The ECB, at the centre of the SSM, is responsible for oversight of the SSM and for the direct supervision of some 129 banking groups. It must apply the EU banking rule-book and is subject to EBA's supervisory convergence and other measures. But the potential for destructive tensions and confusion as EBA and the ECB/SSM interact and their respective spheres of competence overlap is considerable. EBA's engagement with international financial governance must therefore be situated within the wider EBA/ECB/SSM relationship and the distinct incentives it generates. On the one hand, EBA has strong incentives to focus its resources and its political/institutional capital on protecting its position within the EU, particularly given the ECB's constitutionally and substantively more powerful position. ${ }^{71}$ On the other hand, international financial governance may provide a means for EBA to strengthen its capacity and, at the same time, to build a productive relationship with the ECB by their collectively promoting EU interests through what might be termed an EU 'axis of expertise', particularly as the ECB is developing an international supervisory presence through Memoranda of Understanding with third-country bank supervisors ${ }^{72}$ as well as its seat on the Basel Committee. EBA's incentives are, however, likely to be dynamic and, at the moment, are hard to predict as Brexit is likely to destabilise an already delicate institutional equilibrium. On the UK's exit from the EU, one of the major frictions preventing euro area/Banking Union interests and preferences from dictating the shape of single market financial governance will be removed-as is clear from the February 2016 New Settlement which the UK negotiated and which was in part designed to protect the single market from euro area caucusing. ${ }^{73}$ It is hard to dismiss speculation that further centralisation of institutional governance will occur, particularly given political support in the euro area for a 'Financial Union', ${ }^{74}$ and that EBA's role may change significantly.

\footnotetext{
71 See further Ferran (2015) and Moloney (2014b).

72 ECB (2015a), at p. 26.

73 Decision of the Heads of State or Government meeting within the European Council, concerning a new settlement for the United Kingdom with the European Union, European Council Meeting, 18 and 19 February 2016, EUCO 1/16 (Annex 1).

74 Notably in the 'Five Presidents' Report': Completing Europe's Economic and Monetary Union, report by Jean-Claude Juncker, in close cooperation with Donald Tusk, Jeroen Dijsselbloem, Mario Draghi and Martin Schulz (2015). On Financial Union and its implications for institutional governance, see further Moloney (2016).
} 
While all three ESAs are therefore becoming increasingly significant administrative actors in international financial governance, ESMA provides the most extensive and stable case study and is considered in the following Section.

\section{ESMA and International Financial Governance}

\subsection{ESMA Incentives and Powers}

Like EBA and EIOPA, ESMA has significant incentives to engage with international financial governance as a means for strengthening its institutional position. The limitations on its capacity to operate as a quasi-rule-maker are clear from the occasions on which the Commission has rejected or revised ESMA's

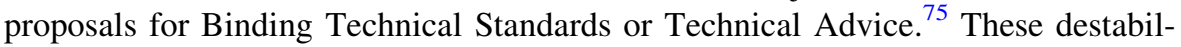
ising episodes are exceptional, but they underline the hierarchically inferior position of ESMA despite its technocratic expertise. ESMA also operates with a degree of constitutional ambiguity with respect to its supervisory powers. Its novel power to impose prohibitions or conditions on short selling in national markets, for example, was challenged by the UK as being in breach of, inter alia, the Meroni principle. Although the 2014 ruling by the Court of Justice of the EU found the power to be valid, ${ }^{76}$ ESMA has significant incentives to deploy its direct supervisory and enforcement powers sparingly so as to manage litigation risk. And while-by contrast with EBA - the ECB/SSM does not yet pose a direct challenge to ESMA, ${ }^{77}$ the increasing global interest of prudential regulators in securities market risksclear from the current and contested focus on the risks which asset management poses to financial stability ${ }^{78}$ - may come to pose a threat to ESMA's reach over EU securities markets. This is all the more the case as conduct risk, the traditional purview of securities regulators, is being clawed into the sphere of influence of prudential regulators. $^{79}$

International financial governance, however, affords ESMA opportunities to strengthen its capacity and institutional position. The field is not clear for ESMA. The disruptive effects of Member State interests aside, the Commission has long provided collective EU representation with respect to securities market matters (IOSCO) and financial reporting (IFRS Foundation). It is also the main actor in the bilateral Joint EU-US Financial Regulatory Forum with respect to financial market

\footnotetext{
75 The lengthy and complex 2014 Markets in Financial Instruments Directive II /Regulation rule-making process most recently illustrates the tensions, with ESMA robustly resisting changes the Commission made to certain of its proposals: ESMA Opinion, 30 May 2016 (ESMA/2016/730).

76 Case C-270/12 UK v Council and Parliament, 22 January 2014.

77 See further Moloney (2015).

78 Best illustrated by the FSB's recent controversial reform initiatives (notably FSB (2016)).

79 Conduct risk formed part of the 2016 stress testing of EU banks EBA (2016b). Internationally, the FSB has recently focused on misconduct as a threat to financial stability: FSB (2015d) and FSB Chairman Letter to G20 Leaders, November 2015.
} 
matters. ${ }^{80}$ But ESMA has been conferred with a series of formal powers with respect to international financial governance and is emerging as an effective presence internationally. Despite a significant budget cut for 2015, ESMA chose not to weaken its international activities that year, ${ }^{81}$ while its 2016 Work Programme showed a similar commitment to international engagement. ${ }^{82}$ The main channels through which ESMA engages with international financial governance are discussed below.

\subsection{Equivalence Decisions}

In the wake of the Brexit decision much attention has focused on the equivalence determinations which the UK may become subject to as a third country seeking access to the EU single market. Any such decisions will be heavily influenced by ESMA, which has become a key actor in this area.

A complex patchwork of rules applies to equivalence determinations in EU financial markets law. Some EU measures do not address or harmonise the thirdcountry access decision, leaving it to the Member States. Others, however, require a positive equivalence determination prior to access being permitted by the Member State in question. In some measures detailed conditions specify how the decision is to be taken, in others there is limited specification. Typically, the Commission, advised by ESMA, must adopt a positive equivalence decision before a Member State can choose to admit a third-country actor. ${ }^{83}$ Equivalence applies not only to formal regulatory equivalence, but also to third-country supervision and enforcement regimes. ${ }^{84}$ A positive equivalence decision is also required where the market access decision is made at EU level (in effect by ESMA) and before the limited group of third-country actors which are eligible for EU access through ESMA registration can be so registered. ${ }^{85}$

\footnotetext{
80 The Forum originally took the form of the 'Financial Markets Regulatory Dialogue'. Its recasting as a Forum in July 2016 did not see the ESAs become more prominent, formally at least: Commission, Improvements in EU-U.S. Regulatory Cooperation, 18 July 2016.

81 International activities were not included among the originally planned activities which ESMA subsequently removed from its 2015 Annual Work Plan, following its 15\% budget cut (ESMA/2014/1200 Rev, at pp. 32-33).

82 ESMA, Work Programme 2016 (ESMA/2015/1475), noting, e.g., cooperation with IOSCO on a number of fronts, coordination with the FSB on benchmark regulation, and a commitment to international activities generally.

83 On the EU approach to the prospectus, investment services, credit rating agency, alternative investment fund and OTC derivative sectors, see Moloney (2014a), at pp. 122-124, 404-407, 677-682, 307-311 and 615-629.

84 E.g., 2014 Markets in Financial Instruments Regulation, Art. 47.

85 E.g., 2012 European Market Infrastructure Regulation [Regulation (EU) No 648/2012, OJ L 2012 201/1], Art. 25 (third-country CCPs) and Art. 77 (third-country trade repositories); and 2011 Credit Rating Agency Regulation [Regulation (EU) No 513/2011, OJ L 2011 145/30], Arts. 4 and 5 (thirdcountry rating agencies).
} 
Any equivalence determination is discretionary and judgment based as it typically relates equivalence to outcomes. ${ }^{86}$ It therefore places ESMA, in advising the Commission, at the heart of complex and politically sensitive market access determinations associated with state 'power as autonomy', ${ }^{87}$ and in a position accordingly to exert and strengthen EU influence internationally. A somewhat timorous approach might have been expected: ESMA, as a youthful actor, has strong incentives to build effective relationships with regulators internationally and similarly strong incentives not to antagonise major global market operators. Its approach has nonetheless been robust and suggests an ability to establish a credible presence in international financial governance. With respect to rating agency regulation equivalence, for example, it adopted a relatively intrusive approach. ${ }^{88}$ With respect to asset manager market access, ESMA provoked some consternation in the global fund market in July 2015 when it declined to offer an opinion (as required under the complex third-country access requirements of the 2011 Alternative Investment Fund Managers Directive ${ }^{89}$ ) as to whether the regulatory 'passport' to the single market currently enjoyed by EU funds and their managers should be extended to funds and managers from a series of jurisdictions, including Hong Kong and the US, given insufficient data. ${ }^{90}$ ESMA finally adopted a 'positive' opinion in July 2016 with respect to access by a number of third-country jurisdictions, including Canada and Switzerland. The opinion revealed the granular and detailed analysis which ESMA had undertaken, including with respect to the operation of relevant MoUs, authorisation procedures, investor protection, and enforcement capacity. ${ }^{91}$ It also underlined ESMA's willingness to adopt a firm approach. ESMA declined to adopt a positive opinion in relation to certain jurisdictions, and adopted a qualified approach to others (including the US and Hong Kong). It has also, however, shown itself as politically adept. The protracted equivalence negotiations on central clearing counterparty (CCP) equivalence between the EU and US involved high-level Commission discussions as well as technical ESMA negotiations. Ultimately, the issue was resolved at Commission/US Commodities Futures Trading Commission level in February 2016 by means of the adoption of a 'common approach'. 92 ESMA subsequently indicated that 'it would do everything within its powers' to shorten the related ESMA procedures for

\footnotetext{
86 As is the case, e.g., with respect to equivalence determinations relating to the equivalence of CCP regimes.

87 Helleiner and Pagliari (2011).

88 ESMA's equivalence assessment follows an 'objective' approach, based on the capacity of the thirdcountry regime to meet the objectives of the EU regime. It focuses in particular on the scope of the regulatory and supervisory framework, corporate governance, conflicts of interest management, organisational requirements, quality of methodologies and of ratings, disclosure, and effective supervision and enforcement: ESMA (2012a), at pp. 5-6.

89 Directive 2011/61/EU, OJ 2011 L174/1.

90 While the exercise was not formally an equivalence assessment, it involved a similar assessment. ESMA declined to reach a view given concerns related to competition, regulation, and a lack of sufficient evidence to properly assess the relevant criteria: ESMA (2015a).

91 ESMA (2016b).

92 See supra n. 42. The formal equivalence decisions by the Commission followed in March 2016.
} 
registering third-country CCPs within the EU (by June 2016 any third-country CCP was required to be assessed as subject to an equivalent regime to the EU regime, and registered by ESMA, in order to be eligible to clear certain instruments in the EU). ${ }^{93}$

Overall, recent experience suggests that ESMA has significantly enhanced the EU's ability to make independent, potentially unpopular, and technically robust equivalence determinations and so to drive (or 'cross-load') the imposition of EU preferences internationally, particularly where jurisdictions are required to adapt their regime to the EU requirements. ${ }^{94}$ But, and perhaps paradoxically as market access decisions can generate regulatory friction, it also suggests that ESMA may come to strengthen international financial governance by developing and deepening contacts with peer regulators internationally (not least as EU equivalence/market access tests typically impose requirements relating to international information exchange and supervisory cooperation agreements) and increasing understanding of regulatory, supervisory, and enforcement processes internationally.

\subsection{Financial Reporting and the IFRS Foundation}

The EU/IFRS Foundation relationship is a key one for the EU. IFRS, adopted by the IFRS Foundation, are the mandatory EU financial reporting standards for the consolidated accounts of EU firms listed on 'first tier' trading venues (or 'regulated markets'). Much of EU/IFRS Foundation engagement has historically taken place through the Commission. More recently, an EU committee (the Accounting Regulatory Committee-ARC) and a technical advisory group (the European Financial Reporting Advisory Group-EFRAG), both of which advise the Commission on its adoption for the EU of IFRS (through the IFRS 'endorsement' process), have played supporting roles. ESMA, however, has recently emerged as a significant actor in EU/IFRS Foundation relations. Directly enjoined to address financial reporting, ${ }^{95}$ well equipped to exploit a fragmented EU institutional environment which has multiple national and EU-level components, ${ }^{96}$ and committed to enhancing IFRS convergence, ${ }^{97}$ ESMA has moved to claim ownership over IFRS Foundation engagement and looks set to strengthen EU influence.

ESMA has engaged actively with the IFRS Foundation on the development of IFRS. ${ }^{98}$ It has also carved out an oversight role with respect to the application of IFRS in the EU. It has, for example, produced a series of own-initiative statements on IFRS which cover, inter alia, the quality of financial reporting and the avoidance

\footnotetext{
93 ESMA Statement, 10 February 2016 (ESMA/2016/278).

94 As was the case with respect to US rating agency regulation.

952010 ESMA Regulation Art. 29(1)(c).

96 The IFRS Foundation has noted that it is difficult for the EU to present a consistent position given the different national bodies and EU-level bodies which engage with the IFRS Foundation: Maystadt (2013).

97 ESMA Chairman Maijoor highlighted in his first term that pan-EU coordination of IFRS was one of ESMA's primary objectives: Speech on 'Developments in European Financial Reporting', 12 November 2012.

98 In 2014, e.g., ESMA provided 21 comment letters on various IFRS consultations and agenda matters: ESMA (2015b), at p. 4. In 2015, it provided some 11 responses and engaged in multiple working groups: ESMA (2016c), at pp. 26-27.
} 
of 'boiler plate', 99 the treatment of loan forbearance practices, ${ }^{100}$ and the treatment of sovereign debt disclosures. ${ }^{101}$ While in all cases ESMA has been careful to underline that it does not interpret IFRS, and so does not seek to overstep the IFRS Foundation's interpretive jurisdiction, it typically also stresses that national authorities should reflect its approach in their local IFRS enforcement activities and that auditors and firms in the EU should consider its findings. Similarly, through its European Enforcers Coordination Sessions (EECS), ${ }^{102}$ which are designed to support EU convergence on IFRS enforcement decisions, ESMA has reviewed national enforcement of IFRS. ESMA has also adopted common enforcement priorities for national enforcement authorities with respect to IFRS application. ${ }^{103}$

ESMA's engagement may, however, exacerbate long-standing EU/IFRS Foundation tensions, to the detriment of the EU's effectiveness in imposing its preferences, and generate risks to the integrity of IFRS globally. The Foundation's interests as a private standard-setting body, with a global agenda and open to an array of influences, ${ }^{104}$ have at times conflicted with the particular interests pursued by the EU. In 2004, for example, the IAS 39 fracas, which led to the EU 'carving out' from the IAS 39 standard in order to protect parts of the EU banking sector, generated an international furore given the threat to the global integrity of IFRS. ${ }^{105}$ Tensions emerged again over the financial crisis when, under pressure from the EU, the Foundation made an urgent reform to IAS 39 to reflect the severe market volatility and illiquidity which was causing difficulties for mark-to-market valuations by EU banks. Although the EU has often been successful in imposing its preferences, ${ }^{106}$ EU/IFRS Foundation relations can be unstable and the consequences for global IFRS consistency prejudicial. These difficulties may be exacerbated by ESMA's intensifying engagement, to the detriment of both the EU's ability to impose its preferences and the IFRS Foundation's ability to achieve convergence on the application of IFRS. In particular, any incursions by ESMA into what might be perceived as the interpretation of IFRS may generate tensions. Difficulties may also arise within the EU. Significant tensions already exist between ESMA and the ARC/EFRAG bodies involved in the EU IFRS endorsement process, and these may destabilise wider EU/IFRS Foundation relations. ${ }^{107}$ And the potential for prejudicial Commission/ESMA tensions is not insignificant given the

\footnotetext{
99 ESMA/2015/1609.

100 ESMA/2012/853.

101 ESMA/2011/226 and ESMA/2011/397.

102 Composed of some 37 financial reporting enforcement authorities from across the EU and EEA.

103 The common enforcement priorities for the 2015 financial statements of listed firms include the treatment by companies of the impact of financial market conditions on financial statements and fair value measurement (ESMA 2016c).

104 Fleckner (2008).

105 Whittington (2005).

106 Quaglia (2014a), at pp. 129-146.

107 ESMA and the other ESAs have expressed strong opposition to the persistence of private sector involvement on EFRAG and have refused to sit as voting members on EFRAG (ESA-2014-001).
} 
Commission's role as the EU representative on the IFRS Foundation Monitoring Board as well as its long history in leading the EU charge on issues of IFRS controversy.

Some signs augur well, however, at least from an EU effectiveness perspective. ESMA's extensive experience in collating data from national IFRS enforcers in the EU, in developing collective Board of Supervisors' positions on IFRS consultations, and in consulting and engaging with an array of stakeholders on IFRS allows it to engage with the IFRS Foundation from a position of strength, even if the technical adoption/endorsement of IFRS for the EU is carried out by the Commission. ESMA has achieved an early success in the form of a 2014 Protocol on ESMA and IFRS Foundation cooperation which clarifies ESMA's role with respect to the Foundation and the Foundation's commitment to operational cooperation with ESMA. ${ }^{108}$ Similarly, ESMA/IFRS Foundation communications over the 2015 Review of Structure and Effectiveness of the IFRS Foundation appear to have been productive. ${ }^{109}$ Through its IFRS Foundation engagement ESMA has also opened up another channel through which long-standing EU dissatisfaction with the failure of the US to adopt IFRS ${ }^{110}$ and the EU's perception that the US is over-represented on the Foundation ${ }^{111}$ can be communicated. Overall, the EU's ability to impose its preferences can be expected to strengthen.

From the perspective of the IFRS Foundation, ESMA engagement should strengthen the Foundation's effectiveness internationally. The more concentrated management of EU relations through ESMA - a technocratic and not overtly political actor-should at least minimise EU/Foundation tensions, as long as ESMA is careful in its management of IFRS interpretations. The ability of ESMA to 'upload' to the Foundation the collective EU experience with the implementation and application of IFRS should enhance the ability of the Foundation to revise and refresh IFRS: for example, over 2016, ESMA is to review experience with a number of IFRS standards and to contribute thereby to the Foundation's review. ${ }^{112}$ ESMA engagement may also strengthen the global diffusion of IFRS. ESMA's oversight of enforcement within the EU of IFRS application strengthens the consistency with which IFRS are applied in the EU. ESMA may also prompt the diffusion of IFRS more generally. To take a live example, ESMA is playing an active part in the current EU Capital Markets Union-related discussions on whether a tailored (nonIFRS) harmonised EU reporting standard should apply to firms admitted to the EU's 'second tier' trading venues (to which IFRS do not apply). The related debate

\footnotetext{
108 IFRS Foundation and ESMA Statement of Protocols for Cooperation on IFRS, 9 July 2014.

109 In its response to the Review, ESMA noted that it supported the basic elements of the governance structure and the enhancements proposed by the IFRS Foundation, although it called for more efforts to be made to support public accountability (ESMA/2015/1738).

110 SEC Chief Accountant J Schnurr, Remarks before the 2015 Baruch College Financial Reporting Conference, 7 May 2015.

111 See, e.g., European Commission (2010).

112 ESMA (2016c), at p. 25.
} 
touches on the role of the IFRS 'SME standard'113 which cannot be applied to trading venues. ${ }^{114}$ Whether or not the EU ultimately adopts a new accounting standard for these venues (initial indications suggest not ${ }^{115}$ ), the debate may signal the potential of the IFRS SME standard as a means for supporting SME access to finance in other jurisdictions. ${ }^{116}$ Similarly, ESMA may support the consistent global diffusion of IFRS 9, the important but controversial new accounting standard which forms part of the G20 reform agenda and which addresses, inter alia, the reporting of impaired loans and has major implications for reporting by banks. Following the July 2014 adoption of the standard by the IFRS Foundation, the 'endorsement' process is underway in the EU. ${ }^{117}$ ESMA urged that the standard should be endorsed by the EU on a 'timely basis'; called for early application in the EU; and rejected with some force EFRAG's initial suggestion that the application of IFRS 9 to certain aspects of insurance business be deferred, warning that a 'European carve-out' would not be a feasible solution. ${ }^{118}$ While it remains to be seen whether an EUspecific change to IFRS 9 will be adopted with respect to insurance business, ESMA's intervention underlines its ability to bring a robust technical capacity to bear and its concern to reduce the risk of the EU disrupting the international consistency of IFRS.

\subsection{IOSCO and International Financial Market Standards and Supervision}

ESMA is also developing a strong international presence on other ISSBs, notably IOSCO, which has previously been regarded as a weak point with respect to the EU's ability to impose its preferences, particularly in the face of US power. ${ }^{119}$

ESMA, like the Commission, is a non-voting associate member of IOSCO. But unlike the Commission, ESMA enjoys observer status on the IOSCO Board and on a range of Board policy committees, reflecting its distinct supervisory competences. ${ }^{120}$ This enhancement of ESMA's role is not only a consequence of its distinct powers, however. It can also be explained as reflecting the array of channels

\footnotetext{
113 'IFRS for SMEs' were originally adopted in 2009. They require some $90 \%$ fewer disclosures than full-blown IFRS. The standards can be used by any jurisdiction-whether or not it has adopted IFRS—but not by listed companies or by financial institutions.

114 ESMA (2015c), at pp. 9-10.

115 Stakeholder reaction has tended to be hostile (e.g., European Parliament, Resolution on building a Capital Markets Union, 1 July 2015 (B8-0655/2015), para. 6).

116 As at May 2014, 78 jurisdictions were using the standard: IFRS Foundation, IFRS for SMEs Fact Sheet, February 2016.

117 In May 2015, EFRAG produced its draft endorsement advice for the Commission which provided that the standard complied with the technical endorsement criteria which apply under EU law to IFRS endorsement but suggested a deferral might be required with respect to its insurance-related elements. In September 2015, EFRAG subsequently confirmed its view that the standard be endorsed. The ARC subsequently voted in favour of endorsement in June 2016 and endorsement by the Commission is expected by the end of 2016.

118 ESMA Letter to EFRAG, EFRAG Draft Endorsement Advice on Adoption of IFRS 9, 29 June 2015 (ESMA/2015/1056).

119 Quaglia (2014a), at pp. 105-108.

120 Conac (2015).
} 
through which ESMA has come to build its capacity and credibility among the community of international securities regulators and the strengthening influence of the EU accordingly.

Much of ESMA's interaction with IOSCO arises from ESMA's support of the IOSCO standards which have been adopted on foot of the G20 reform agenda and which ESMA has used to develop the EU's administrative rule-book, whether through its proposals for Binding Technical Standards or its Technical Advice. ${ }^{121}$ ESMA has also drawn on IOSCO standards in its own-initiative work. In developing its own-initiative 2012 Guidelines on automated and algorithmic trading it liaised closely with IOSCO. ${ }^{122}$ Similarly, its 2013 own-initiative Guidelines on the treatment of benchmarks ${ }^{123}$ reflected IOSCO's standards in this area. ${ }^{124}$

ESMA is also building independent relationships with the securities market regulators which sit on IOSCO through its information-exchange and cooperationbased powers and activities. Under the 2011 Alternative Investment Fund Managers Directive ESMA centrally negotiated cooperation arrangements (MoUs) between its constituent member regulators and 50 third-country regulators (more than 1,000 bilateral MoUs were adopted), based on an ESMA MoU template agreed by its Board of Supervisors. As well as deepening ESMA's relationship with third-country regulators, this significant operational success ${ }^{125}$ sent a clear signal internationally as to ESMA's ability to act on behalf of its member regulators in international negotiations and as to the willingness of its member regulators to confer a mandate on ESMA to negotiate on their behalf. Less dramatically - but with no less practical importance given their novelty and their capacity to signal ESMA's credibilityESMA bilaterally entered into a number of MoUs with leading third-country regulators relating to third-country $\mathrm{CCP}$ registration by ESMA. ${ }^{126}$

ESMA has also established a technical presence on the $\mathrm{FSB}^{127}$ and is active in the more informal bodies which support international regulatory coordination. Chief among these are the OTC Derivatives Regulators Group and Forum (ODRG and ODRF) through which ESMA works with other major regulators to address gaps and inconsistencies in the implementation of the G20 OTC derivatives market

\footnotetext{
121 E.g., the extensive organisational, conduct, and prudential EU administrative rules which apply to CCPs and which were developed by ESMA are based in part on the 2012 CPSS-IOSCO Principles for Financial Market Infrastructures.

122 ESMA (2012b). Throughout the Guidelines' development, ESMA emphasised its engagement with international developments, including IOSCO's work on direct market access (Consultation Paper ESMA/2011/224, at pp. 7-8).

123 ESMA/EBA (2013).

124 Over 2013, IOSCO produced two major consultations on principles for financial benchmarks and in July 2013 adopted its Principles for Financial Benchmarks.

125 ESMA Chairman Maijoor described the MoU process as an important step which helped the EU to speak with one voice, ensured a level playing field and greater negotiation efficiency, and "was in some ways a perfect illustration of what the new ESFS can achieve': Speech on ESMA-Issues and Priorities, 5 November 2013 (ESMA/2013/1582).

126 For an example, see the MoU between the Australian regulator (ASIC) and ESMA, available at http://www.esma.europa.eu/system/files/esma_asic_mou_2.pdf. As noted in Sect. 4.2 above, ESMA is required to register third-country CCPs operating in the EU.

127 Through the FSB's 'Legal Entity Identifier' Workstream.
} 
reform agenda. ${ }^{128}$ ESMA is active on the current FSB and ODRF work streams on improving access to and use of the massive data set now emerging from trade repositories for OTC derivatives markets data. ${ }^{129}$ The difficulties associated with the usability of this operationally critical data set include problems with respect to data quality, usability, and aggregation (including on a cross-border basis). ${ }^{130}$ With the ability to communicate the collective experience of (at present) 28 markets and regulators, ESMA is strongly placed to influence remedial and reform initiatives. Similarly, ESMA is entering into agreements with regulators internationally who do not have access to trade repository data. ${ }^{131}$

ESMA's supervisory activities, and in particular its role as direct EU supervisor of the three major global rating agency groups, its responsibility for registering certain actors authorised in third countries, and its oversight role in relation to the EU's novel cross-border supervisory colleges for CCPs, ${ }^{132}$ are also likely to strengthen its international network of securities regulators and its credibility on operational supervisory matters and coordination challenges.

The ability of the EU to impose, via ESMA, its preferences on IOSCO is, accordingly, likely to strengthen. With respect to the implications for IOSCO and for international financial governance, ESMA strengthens the EU's regulatory capacity to support the global diffusion of IOSCO standards and their effective implementation. Where ESMA incorporates IOSCO standards in its Technical Advice or in its proposed Binding Technical Standards, it acts as a 'hardening' or 'legalising' mechanism: it signals the credibility of the standard and supports its global diffusion - the standard may also be 'hardened' where equivalence requirements follow. ${ }^{133}$ ESMA can also 'harden' a standard through its owninitiative soft law activities which provide an additional administrative means through which IOSCO standards can be diffused. Beyond standard implementation, ESMA's operational experience with peer review, data management, supervisory coordination and convergence, and risk monitoring-derived in a regional/multilateral context-is likely to enhance IOSCO's ability to manage difference and coordination on a global basis. For example, ESMA has enhanced its peer review tools, ${ }^{134}$ has expanded its peer review activities, ${ }^{135}$ and is increasingly adopting a

\footnotetext{
128 ESMA (2015d), at p. 64, and ESMA (2016d), at p. 18.

129 It has called for the Forum's mandate to be extended to cover the efficient use of trade repository data: ESMA (2015d), at p. 63.

130 FSB (2015e), at pp. 21-22.

131 Its first access agreement was signed with the Australian regulator (ASIC) in 2014: ESMA (2015d), at p. 63 .

132 ESMA's responsibilities include peer review of colleges and stress testing. See ESMA (2015e) and ESMA (2016e).

133 Bach and Newman (2014).

134 Following the recommendation of the IMF that its peer review function become less peer-driven and more ESMA-led [IMF (2013), at p. 14]. Peer review is a standing item on the agenda of the ESMA Board of Supervisors. Recent refinements include new principles governing stakeholder engagement in peer review (ESMA/2016/632).

135 Recent examples include its peer review of market abuse supervision (ESMA/2015/1905), short selling rule application (ESMA/2015/1791), and suitability requirements supervision (ESMA/2016/584).
} 
more critical and searching tone in its reviews of its constituent national regulators. ${ }^{136}$ It can be expected to share this expertise to strengthen its credibility and capacity in IOSCO, which is now subject to requests from the FSB to carry out peer reviews. $^{137}$

There is a risk of disruption. National regulators ultimately determine decisionmaking in the ESMA Board of Supervisors. ESMA's mandate to act on behalf of the Board of Supervisors may, accordingly, change and be disrupted by national interests. Internal institutional tensions may also arise with the Commission if ESMA begins to eclipse it on IOSCO. ${ }^{138}$ Overall, however, ESMA's incentives and powers and the shifting nature of international financial governance suggest that its influence internationally_and the EU's ability to impose its preferences-will strengthen.

\section{The Impact of Brexit on the 'Agencification' of EU Financial Governance}

On exit from the EU, the UK's representation on the ESAs will change. If an EEA model is adopted for UK/EU engagement, the UK will have observer but non-voting status. If another model is adopted, the UK will no longer be a member of the ESAs. Either way, the UK's ability to shape ESA decision-making, including internationally, will be minimal. While the implications can only be a matter of speculation, a number of predictions can be made.

First, the UK will lose a channel for influencing international financial governance. As a member of the major ISSBs, the UK will continue to advocate directly for UK interests, as it did during the Basel Committee negotiations on the pivotal crisis-era Basel III reforms. But it will lose the additional platform for diffusing preferences which the ESAs provide on the ISSBs. It will also lose the ability to shape how new international standards are implemented in the EU by influencing the development by the ESAs of the related technical administrative rules which can significantly shape business models and practices. This loss of influence is likely to matter given that, assuming that the UK will seek some form of single market access, regulatory equivalence requirements will apply. The UK will also lose the ability to shape the ESAs' still evolving approach to supervisory and enforcement equivalence-these two elements of equivalence are notoriously intractable and elusive.

Second, the withdrawal of the UK is likely to have implications for the ESAs with respect to their international activities. The ESAs have been in operation for over five years and the loss of the technical expertise which UK regulators provide on their many working groups and committees is unlikely to be as disruptive as it

\footnotetext{
136 Notably in its 2015 best execution peer review (ESMA/2015/494), which adopted a significantly more critical tone than earlier reviews.

137 See, e.g., IOSCO (2014), which followed an FSB request.

138 On Commission/agency tensions generally with respect to international engagement, see Chiti (2009).
} 
might have been at the outset. Nonetheless, the ESAs will lose access to a deep pool of technically expert regulators accustomed to dealing with the challenges of a large and complex financial system and with access to a global network of regulatory relationships. The ESAs may, however, find it easier to come to collective positions on their Boards of Supervisors in the absence of the largest financial market in Europe and its distinct preferences, and upon the removal of a strong and potentially coalition-leading voice on the design of EU financial governance. In particular, while the UK has long been a supporter of the ESAs' role in developing the single rule-book, it has been significantly more sceptical with respect to the ESAs' supervisory powers and concerned to protect the Meroni constraint, as is clear from the short selling litigation. In the absence of the friction provided by the UK, the ESAs may prove more willing to test their powers, including by means of a more assertive presence internationally.

More radical consequences may follow, but here predictions can only be highly speculative. Fundamental changes to the institutional underpinnings of EU financial governance typically follow a resetting shock, as was the case with the establishment of the ESAs in 2011 (following the financial crisis) and of the Single Supervisory Mechanism and Single Resolution Mechanism in 2014 and 2015 (following the euro area crisis). UK withdrawal may deliver the third such resetting shock and lead to a recasting of the current unstable euro area/single market arrangement and to governance arrangements which reflect euro area/Banking Union preferences. Given that the euro area has already committed to risk sharing through Banking Union and has supported the related institutional structures for the mutualisation of supervisory risk, spill-over institutional governance consequences may follow. These may include a reorganisation of the ESAs to reflect euro area preferences. This is all the more likely given the current indications of some euro area support for a Financial Union (encompassing Banking Union) with centralised institutional governance. ${ }^{139}$ The ECB has already signalled its support for more centralised capital markets supervision in a euro area Financial Union which would 'complete' Economic and Monetary Union. ${ }^{140}$ Any such institutional reorganisation, which would probably require Treaty change, would imply a resetting change to how the EU engages with international financial governance, particularly if new forms of 'Single Supervisory Mechanism' for the EU insurance and securities markets were to emerge. Given the EU's attachment to 'off the shelf' solutions when it comes to institutional governance design, the most likely model would be a twin peaks model built on current institutional structures. Given the availability of the ECB/SSM, centralised prudential supervision arrangements could be located in an ECB-based 'mechanism' and, given the availability of ESMA, conduct supervision arrangements could be located in a (retooled) ESMA-based 'mechanism'. Were this to transpire, the nature of the EU's engagement with international financial governance would change radically and would likely be mediated through two powerful EU supervisors.

\footnotetext{
139 See supra n. 74.

140 ECB (2015b).
} 


\section{An Assessment}

What then might be concluded as to the recent 'agencification' of the EU's interaction with international financial governance? This article suggests that international financial governance is becoming more operational and that administrative actors-notably financial regulators-are becoming more influential. In tandem with this development, the ESAs are constructing a new administrative channel through which the EU is engaging with international financial governance. This channel presents the EU with significant opportunities for strengthening its regulatory capacity internationally and also has implications for the effectiveness of international financial governance more generally. The ESMA case study suggests that the EU's ability to impose its preferences internationally is likely to be significantly enhanced. From the international governance perspective, ESMA is likely to support wider international diffusion of standards, deeper sharing of experiences and best practices concerning coordination and risk management, and more stable regulatory relations. The persistence of a degree of constructive ambiguity and tension in how the ESAs interact with international financial governance, including with respect to relations with the national regulators on their Boards of Supervisors, is likely to be productive. National interests and experiences should, reflecting the persistent structural differences across the EU's economies and financial systems, continue to inform international engagement, alongside the collective EU interest and experience. This is all the more the case as the extent to which the ESAs' current accountability structures, which are primarily based on institutional reporting, can support their intensifying activities is not clear-full coverage of this issue, which intersects with the global administrative law analysis, is outside the scope of this discussion.

It remains to be seen how the current environment will change on Brexit. This article predicts that Brexit and the withdrawal of the UK from the ESAs will result in a diminution of UK influence internationally and may also generate existential consequences for the current EU governance settlement, potentially leading to the construction of new and powerful regulatory authorities through which international financial relations will be conducted.

Open Access This article is distributed under the terms of the Creative Commons Attribution 4.0 International License (http://creativecommons.org/licenses/by/4.0/), which permits unrestricted use, distribution, and reproduction in any medium, provided you give appropriate credit to the original author(s) and the source, provide a link to the Creative Commons license, and indicate if changes were made.

\section{References}

Amtenbrick F (2013) What role for the EU in shaping global financial governance? In: Van Vooren B, Blockmans S, Wouters J (eds) The EU's role in global governance. Oxford University Press, Oxford Avgouleas E (2012) Governance of global financial markets. The law, the economics, the politics. Cambridge University Press, Cambridge

Bach D, Newman A (2007) The European regulatory state and global public policy: micro-institutions, macro-influence. Journal of European Public Policy 14:827-846 
Bach D, Newman A (2014) The European Union as hardening agent: soft law and the diffusion of global financial regulation. Journal of European Public Policy 21:430-452

Barr M (2014) Who's in charge of global finance? Georgetown Journal of International Law 45:971-1027

Barr M, Miller G (2006) Global administrative law: the view from Basel. Eur J Int Law 17:15-46

Basel Committee on Banking Supervision (2014a). Regulatory Consistency Assessment Program (RCAP) Assessment of Basel III regulations-European Union. http://www.bis.org/bcbs/publ/d300.pdf. Accessed Aug 2016

Basel Committee on Banking Supervision (2014b) Principles for effective supervisory colleges. http:// www.bis.org/publ/bcbs287.htm. Accessed Aug 2016

Basel Committee on Banking Supervision (2015) Consultative Document. Review of the Credit Valuation Adjustment Risk Framework. http://www.bis.org/bcbs/publ/d325.pdf. Accessed Aug 2016

Basel Committee on Banking Supervision (2016) Tenth progress report on adoption of the Basel regulatory framework. http://www.bis.org/bcbs/publ/d366.pdf Accessed Aug 2016

Blom J (2014) Banking. In: Mügge D (ed) Europe and the governance of global finance. Oxford University Press, Oxford

Brummer C (2011) How international financial law works (and how it doesn't). Georgetown Law Journal 99:257-327

Brummer C (2012) Soft law and the global financial system. Rule-making in the $21^{\text {st }}$ century. Cambridge University Press, Cambridge

Brummer C (2014) Minilateralism. Cambridge University Press, Cambridge

Busuioc M (2013) Rule-making by the European financial supervisory authorities: walking a tight rope. European Law Journal 19:111-125

Büthe T, Mattli W (2011) The new global rulers: the privatization of regulation in the world economy. Princeton University Press, Princeton

Campbell-Verduyn M, Porter T (2014) Experimentalism in European Union and global financial governance: interactions, contrasts, and implications. Journal of European Public Policy 21:408-429

Chiti E (2009) An important part of the EU's institutional machinery: features, problems and perspectives of European agencies. Common Market Law Rev 46:1395-1442

Conac P-H (2015) The European Union's role in international economic fora. Paper 6: The IOSCO. Study for the European Parliament. http://www.europarl.europa.eu/RegData/etudes/STUD/2015/542195/ IPOL_STU(2015)542195_EN.pdf. Accessed Aug 2016

Craig P (2015) UK, EU and global administrative law. Cambridge University Press, Cambridge

Davies H, Green D (2008) Global financial regulation. Polity Press, Cambridge, The essential guide

Drezner D (2007) All politics is global. Explaining international regulatory regimes. Princeton University Press, Princeton, NJ

Dür A (2011) Fortress Europe or open door Europe? The external impact of the EU's single market in financial services. Journal of European Public Policy 18:619-635

European Banking Authority (2014) Guidelines on common procedures and methodologies for the supervisory review and evaluation process. https:/www.eba.europa.eu/documents/10180/935249/ EBA-GL-2014-13+(Guidelines+on+SREP+methodologies+and+processes).pdf. Accessed Aug 2016

European Banking Authority (2016a) Report on the convergence of supervisory practices (EBA/Op/2016/ 11). http://www.eba.europa.eu/documents/10180/1360107/EBA+report+on+the+convergence+ of+supervisory+practices. Accessed Aug 2016

European Banking Authority (2016b) EU-Wide Stress Test. Methodological Note. https://www.eba. europa.eu/documents/10180/1259315/2016+EU-wide+stress+test-Methodological+note.pdf.

Accessed Aug 2016

European Central Bank (2015a) ECB Annual Report on Supervisory Activities. https://www. bankingsupervision.europa.eu/ecb/pub/pdf/ssmar2014.en. pdf?c50e4de7ccc030381567868a76b97e1d. Accessed Aug 2016

European Central Bank (2015b) Building a Capital Markets Union-Eurosystem contribution to the European Commission's Green Paper. https://www.ecb.europa.eu/pub/pdf/other/150521_ eurosystem_contribution_to_green_paper_-_building_a_cmuen.pdf. Accessed Aug 2016

European Commission (2010) Report to the European Securities Committee and to the European Parliament on convergence between International Financial Reporting Standards (IFRS) and third country national Generally Accepted Accounting Principles (GAAPs) (SEC(2010) 681). http://ec. europa.eu/transparency/regdoc/rep/1/2010/EN/1-2010-292-EN-F1-1.Pdf. Accessed Aug 2016 
European Commission (2015) Commission Staff Working Document: initial reflections on the obstacles to the development of deep and integrated EU capital markets (SWD (2015) 13). http://eur-lex. europa.eu/legal-content/EN/TXT/?uri=CELEX:52015SC0013. Accessed Aug 2016

European Insurance and Occupational Pensions Authority (2015a) Multi-Annual Work Programme 2015-2017 (EIOPA/BOS/14/09). https://eiopa.europa.eu/Publications/Administrative/EIOPA_ Multi_Annual_Work_Programme_2015-2017.pdf. Accessed Aug 2016

European Insurance and Occupational Pensions Authority (2015b) Annual Report 2015. https://eiopa. europa.eu/Publications/Reports/EIOPA\%20Annual\%20Report\%202015.pdf. Accessed Aug 2016

European Parliament, ECON Committee (2016) Report on the EU role in the framework of international financial, monetary and regulatory institutions and bodies (March 2016) (A8-0027/2016). http:// www.europarl.europa.eu/sides/getDoc.do?pubRef=-//EP//TEXT+REPORT+A8-2016-0027+0+ $\mathrm{DOC}+\mathrm{XML}+\mathrm{V} 0 / / \mathrm{EN}$. Accessed Aug 2016

European Securities and Markets Authority (2012a) Technical Advice on CRA regulatory equivalenceUS, Canada and Australia (ESMA/2012/259). https:/www.esma.europa.eu/sites/default/files/ library/2015/11/2012_-259_0.pdf. Accessed Aug 2016

European Securities and Markets Authority (2012b) Guidelines. Systems and controls in an automated trading environment for trading platforms, investment firms and competent authorities. https://www. esma.europa.eu/sites/default/files/library/2015/11/esma_2012_122_en.pdf. Accessed Aug 2016

European Securities and Markets Authority (2015a) ESMA's Advice to the European Parliament, the Council and the Commission on the application of the AIFMD passport to non-EU AIFMs and AIFs (ESMA/2015/1236) https://www.esma.europa.eu/sites/default/files/library/2015/11/2015-1236_ advice_to_ep-council-com_on_aifmd_passport.pdf. Accessed Aug 2016

European Securities and Markets Authority (2015b) ESMA Report on Enforcement and Regulatory Activities of Accounting Enforcers in 2014. https://www.esma.europa.eu/sites/default/files/library/ 2015/11/2015-659_activity_report_on_accounting_enforcers_in_europe_in_2014.pdf. Accessed Aug 2016

European Securities and Markets Authority (2015c) ESMA response to the Commission Green Paper on Building a Capital Markets Union (2015/ESMA/856). https://www.esma.europa.eu/sites/default/ files/library/2015/11/esma-2015-856_esma_response_to_ec_green_paper_on_cmu.pdf. Accessed Aug 2016

European Securities and Markets Authority (2015d) ESMA Annual Report 2014. https://www.esma. europa.eu/sites/default/files/library/2015/11/2015-934_-_esma_annual_report_2014_.pdf. Accessed Aug 2016

European Securities and Markets Authority (2015e) ESMA review of CCP colleges under EMIR (ESMA/ 2015/20). https://www.esma.europa.eu/sites/default/files/library/2015/11/2015-20__report_on_ esma_review_of_ccp_colleges.pdf. Accessed Aug 2016

European Securities and Markets Authority (2016a) Supervisory Convergence Work Programme 2016 (ESMA/2016/203). https://www.esma.europa.eu/sites/default/files/library/2016-203_2016_ supervisory_convergence_work_programme.pdf. Accessed Aug 2016

European Securities and Markets Authority (2016b) ESMA's advice to the European Parliament, the Council and the Commission on the application of the AIFMD passport to non-EU AIFMs and AIFs (ESMA/2016/1140). https://www.esma.europa.eu/sites/default/files/library/2016-1140_aifmd_ passport.pdf. Accessed Aug 2016

European Securities and Markets Authority (2016c) ESMA Report on Enforcement and Regulatory Activities of Accounting Enforcers in 2015 (ESMA/2015/410). https:/www.esma.europa.eu/sites/ default/files/library/2016-410_esma_report_on_enforcement_and_regulatory_activities_of_ accounting_enforcers_in_2015.pdf. Accessed Aug 2016

European Securities and Markets Authority (2016d) ESMA Annual Report 2015. https://www.esma. europa.eu/sites/default/files/library/2016-960_esma_annual_report_2015.pdf. Accessed Aug 2016

European Securities and Markets Authority (2016e) EU-Wide CCP Stress Test (ESMA/2016/658). https:// www.esma.europa.eu/press-news/esma-news/esma-publishes-results-eu-central-counterparties-stresstest. Accessed Aug 2016

European Securities and Markets Authority and European Banking Authority (ESMA/EBA) (2013) Principles for benchmark-setting processes in the EU (ESMA/2013/659). https://www.esma.europa.eu/ sites/default/files/library/2015/11/2013-659_esma-eba_principles_for_benchmark-setting_processes_ in_the_eu.pdf. Accessed Aug 2016 
Ferran E (2012a) Crisis-driven regulatory reform: where in the world is the EU going? In: Ferran E, Moloney N, Hill J, Coffee JC. The regulatory aftermath of the global financial crisis. Cambridge University Press, Cambridge

Ferran E (2012b) Capital market openness after financial turmoil. In: Koutrakos P, Evans M (eds) Beyond the established orders-policy interconnections between the EU and the rest of the world. Hart, Oxford

Ferran E (2014) Financial supervision. In: Mügge D (ed) Europe and the governance of global finance. Oxford University Press, Oxford

Ferran E (2015) European Banking Union: imperfect, but it can work. In: Busch D, Ferrarini G (eds) European Banking Union. Oxford University Press, Oxford

Financial Stability Board (2015a) Total loss-absorbing and recapitalisation capacity of G-SIBs in resolution principles. TLAC Term Sheet. http://www.fsb.org/wp-content/uploads/TLAC-Principlesand-Term-Sheet-for-publication-final.pdf. Accessed Aug 2016

Financial Stability Board (2015b) Handbook for FSB Peer Reviews. http://www.financialstabilityboard. org/2015/03/handbook-for-fsb-peer-reviews/. Accessed Aug 2016

Financial Stability Board (2015c) Thematic review on supervisory frameworks and approaches for SIBs. http://www.fsb.org/wp-content/uploads/Thematic-Review-on-Supervisory-Approaches-to-SIBs.pdf. Accessed Aug 2016

Financial Stability Board (2015d) Measures to reduce misconduct risk. Progress report. http://www.fsb. org/wp-content/uploads/Misconduct-risk-progress-report.pdf. Accessed Aug 2016

Financial Stability Board (2015e) OTC derivatives market reform. Ninth progress report on implementation. http://www.financialstabilityboard.org/2015/07/ninth-progress-report-on-implementation-ofotc-derivatives-market-reforms/. Accessed Aug 2016

Financial Stability Board (2015f) OTC derivatives market reform. Tenth progress report on implementation. http://www.fsb.org/wp-content/uploads/OTC-Derivatives-10th-Progress-Report.pdf. Accessed Aug 2016

Financial Stability Board (2015g) Global Shadow Banking Monitoring Report 2015. http://www.fsb.org/ wp-content/uploads/global-shadow-banking-monitoring-report-2015.pdf. Accessed Aug 2016

Financial Stability Board (2016) Proposed policy recommendations to address structural vulnerabilities from asset management activities. http://www.fsb.org/wp-content/uploads/FSB-Asset-ManagementConsultative-Document.pdf. Accessed Aug 2016

Fleckner A (2008) FASB and IASB: dependence despite independence. Virginia Law \& Business Review 3:275-309

Gadinis S (2013a) The Financial Stability Board: the new politics of international financial regulation. Texas International Law Journal 48:157-176

Gadinis S (2013b) From independence to politics in financial regulation. California Law Review 101:327-406

Hall P, Soskice D (2001) Varieties of capitalism. The institutional foundations of comparative advantage. Oxford University Press, Oxford

Hardie I, Howarth D (2013) Market-based banking and the international financial crisis. Oxford University Press, Oxford

Helleiner E, Pagliari S (2011) The end of an era in international financial regulation? A post-crisis research agenda. Int Org 65:169-200

Héritier A, Lehmkuhl D (2008) Introduction: the shadow of hierarchy and new modes of governance. Journal of Public Policy 28:1-17

Howarth D, Quaglia L (2015) The comparative political economy of Basel III in Europe. Europa Working Paper No. 2015/03. http://ssrn.com/abstract=2630555. Accessed Aug 2016

International Association of Insurance Supervisors (2014) Annual Report. http://www.iaisweb.org/page/ about-the-iais/annual-reports. Accessed Aug 2016

International Monetary Fund (2013) Financial Sector Assessment Program. European Union. European Securities and Markets Authority. Technical Note. https://www.imf.org/external/pubs/ft/scr/2013/ cr1369.pdf. Accessed Aug 2016

International Monetary Fund (2015) United States. Detailed assessment of implementation. IOSCO objectives and principles of securities regulation. IMF Country Report No. 15/91. https://www.imf. org/external/pubs/ft/scr/2015/cr1591.pdf. Accessed Aug 2016

International Organization of Securities Commissions (2013) Supervisory Colleges for Credit Rating Agencies: Final Report. https://www.iosco.org/library/pubdocs/pdf/IOSCOPD416.pdf. Accessed Aug 2016 
International Organization of Securities Commissions (2014) Peer Review of Implementation of Incentive Alignment Recommendations for Securitisation: Final Report. https://www.iosco.org/ library/pubdocs/pdf/IOSCOPD504.pdf. Accessed Aug 2016

International Organization of Securities Commissions (2015a) Credible Deterrence in the Enforcement of Securities Regulation. https://www.iosco.org/library/pubdocs/pdf/IOSCOPD490.pdf. Accessed Aug 2016

International Organization of Securities Commissions (2015b) IOSCO Task Force on Cross-Border Regulation. Final Report. https://www.iosco.org/library/pubdocs/pdf/IOSCOPD507.pdf. Accessed Aug 2016

International Organization of Securities Commissions (2016) Securities Markets Risk Outlook 2016. https://www.iosco.org/library/pubdocs/pdf/IOSCOPD527.pdf. Accessed Aug 2016

Kelly C, Cho S (2011) Promises and perils of new global governance: a case of the G20. Chicago Journal of International Law 12:49

Lowet L (2015) The European Union's role in international economic fora. Paper 8: the IAIS. Study for the European Parliament, IP/A/ECON 2014-2015. http://www.europarl.europa.eu/RegData/etudes/ STUD/2015/542197/IPOL_STU(2015)542197_EN.pdf. Accessed 11Aug 2016

Maystadt P (2013) Should IFRS standards be more 'European'? Mission to reinforce the EU's contribution to the development of international accounting standards. Report for the Commission. http://ec.europa.eu/internal_market/accounting/docs/governance/reform/131112_report_en.pdf. Accessed Aug 2016

Moloney N (2010) EU financial market regulation after the global financial crisis: 'more Europe' or more risks? Common Market Law Rev 47:1317-1383

Moloney N (2014a) EU securities and financial markets regulation. Oxford University Press, Oxford

Moloney N (2014b) European Banking Union: assessing its risks and resilience. Common Market Law Rev 51:1609-1670

Moloney N (2015) Banking Union and the implications for financial market governance in the EU: convergence or divergence? In: Busch D, Ferrarini G (eds) European Banking Union. Oxford University Press, Oxford

Moloney N (2016) Institutional governance and Capital Markets Union: incrementalism or a 'big bang'? European Company and Financial Law Review 13:376-423

Moloney N (2017) The EU in international financial governance. Russell Sage Foundation Journal of the Social Sciences, forthcoming

Mügge D (2011) The European presence in global financial governance: a principal agent perspective. Journal of European Public Policy 18:383-402

Mügge D (2014a) Introduction. In: Europe and the governance of global finance. Mügge D. Oxford University Press, Oxford

Mügge D (2014b) Europe's regulatory role in post-crisis global finance. Journal of European Public Policy 21:316-326

Newman A, Posner E (2015) Putting the EU in its place: policy strategies and the global regulatory context. Journal of European Public Policy 22:1316-1335

Pan E (2010) Challenge of international cooperation and institutional design in financial supervision: beyond transgovernmental networks. Chicago Journal of International Law 11:243-284

Posner E (2009) Making rules for global finance: transatlantic regulatory cooperation at the turn of the millennium. Int Org 63:665-699

Posner E (2010) Is a European approach to financial regulation emerging from the crisis. In: Helleiner E, Pagliari S, Zimmerman H (eds) Global finance in crisis. The politics of international regulatory change. Routledge, London and New York

Posner E, Véron N (2010) The EU and financial regulation: power without purpose. Journal of European Public Policy 17:400-415

Quaglia L (2014a) The European Union and global financial regulation. Oxford University Press, Oxford

Quaglia L (2014b) The sources of European influence in international financial regulatory fora. Journal of European Public Policy 21:327-345

Quaglia L (2015) The European Union's role in international economic fora. Paper 5: The BCBS. Study for the European Parliament. http://www.europarl.europa.eu/RegData/etudes/IDAN/2015/542194/ IPOL_IDA(2015)542194_EN.pdf. Accessed Aug 2016

Schammo P (2011) The European Securities and Markets Authority: lifting the veil on the allocation of powers. Common Market Law Rev 48:1879-1914

Slaughter A-M (2004) A new world order. Princeton University Press, Princeton, NJ, and Oxford 
Verdier P-H (2013) The political economy of international financial regulation. Indiana Law Journal $88: 1405-1474$

Whittington $\mathrm{G}$ (2005) The adoption of international financial reporting standards in the European Union. European Accounting Review 14:127-153

Yadav Y (2010) The specter of Sisyphus: re-making international financial regulation after the global financial crisis. Emory International Law Review 24:83-118

Zaring D (2009) International institutional performance in crisis. Chicago Journal of International Law 10:475 